\title{
Impact of Psychological Traits on Rationality of Individual Investors
}

\author{
Bashir Ahmad Joo, Kokab Durri \\ The Business School, University of Kashmir, Srinagar, India \\ Email: drkamagarbashirahmad@uok.edu.in09797063383,kdurri@yahoo.com
}

How to cite this paper: Joo, B.A. and Durri, K. (2018) Impact of Psychological Traits on Rationality of Individual Investors. Theoretical Economics Letters, 8, 1973-1986.

https://doi.org/10.4236/tel.2018.811129

Received: February 26, 2018

Accepted: July 28, 2018

Published: July 31, 2018

Copyright () 2018 by authors and Scientific Research Publishing Inc. This work is licensed under the Creative Commons Attribution International License (CC BY 4.0).

http://creativecommons.org/licenses/by/4.0/

\begin{abstract}
Over the years it has been noted that investors suffer from number of biases that affect their rationality while they take investment decisions and as such it is must for stakeholders to have an idea of these biases. Thus the objective of this paper is to explore the factors which affect the investors' rational behavior in the stock market decisions. The authors have designed well-structured questionnaire to empirically investigate the presence of psychological traits in the individual investors' financial decisions. Deduction approach of research has been used in present study because the main objective of the study is to identify the psychological traits that influence the decision making of individual investors, which are already out there, without inferring and building theory. Based on the data collected from 303 respondents and by applying Exploratory Factor Analysis (EFA), the study could identify the five main psychological traits including the newly identified bias i.e. "faith" that have substantial influence on the rationality of investors. Further, the results of regression analysis reveal that faith, heuristics, confirmation, pessimism, overconfidence and optimism and herd behavior are statistically significant psychological traits and all these variables collectively explain the 35 per cent variation in rational behaviour of investors. Finally, this study asserts that there is an urgent need to have the unified theory of behavioural finance and standard finance, the emphasis of which should be in identifying portfolio anomalies that can be explained by various psychological traits in individual investors for bringing greater efficiency in our stock markets.
\end{abstract}

\section{Keywords}

Psychological Traits, Rationality, Faith, Heuristics, Overconfidence, Optimism, Pessimism

\section{Introduction}

In 1990s rationality assumption of standard finance theory was challenged by the 
behavioral scientists and it was declared incomplete model because standard finance theory does not consider individual behavior of investors. Specifically, according to Olsen [1], behavioral finance seeks to understand and predict systematic financial market implications of psychological and economic principles for the improvement of financial decision making. It was acknowledged that there is need to have unified theory of behavioral finance, the emphasis of which are on identifying portfolio anomalies that can be explained by various psychological traits in individuals or pinpointing instances when it is possible to experience above normal rate of return by exploiting the biases of investors. This is needed because every one of us invests with the motive that it will increase our future consumption and as such we strive hard to maximize return on our investment. In order to maximize return it is assumed under Efficient Market Hypothesis (EMH) relating to traditional finance theory that individual investors behave rationally and their behaviors are in no way dependent on their emotions or psychology [2] [3]. Although, this theory was in a position to succeed in explaining market behaviors and has got universal acceptance but it could not satisfy behavioral scientists because they believe that investors are driven by their emotions and psychological traits. An individual's psychological traits influence ones' behavior and hence influence their financial decisions [4].

Hence, it is a multi-dollar question to study whether or not psychological traits of individual investors have any impact on rationality of individual investors and if at all they have impact on their investment decisions then what are various psychological factors that really have an impact on the investment decisions of individual investors. It is against this back drop, that present study has been undertaken to identify factors those influence the investment decisions of individual investors.

\section{Review of Literature}

Standard finance theories being normative in nature, explained how one should proceed while making investment decisions. These theories provided ways and means for the investors for maximization of returns based on understanding of the fundamentals of companies. Over the years, it was experienced that investors don't follow these advised patterns of investment. Contrary investors were seen to be influenced by the psychological traits to the extent that could not have been neglected and hence it was realized that we need to redefine and readjust our legal fundamentals to the new insights of behavioral finance [5]. The theoretical and experimental work of two famous psychologists Daniel Kahneman and Amos Tversky made some remarkable contributions to psychology literature in 1970's, and build foundation to a new paradigm in the 1980's called "Behavioral Finance", which explains how individual investors behave actually while taking financial decisions. Behavioral finance considers how various psychological traits affect the investment decisions of individuals or groups such as investors, analysts, and portfolio managers etc. In this context, the theories and the 
assumptions of standard finance are no longer valid in isolation because we need to incorporate investor sentiment in it and only then better descriptive model of investment choice under uncertainty can be developed [6]. This is needed because standard finance theories argues that investors are rational and are not affected by psychological traits and do not exhibit any bias in their investment decisions, while as behavioral finance theories argues that such assumptions should be relaxed as all investors are governed by psychological traits at one or other point of time. Behavioral finance is based on the notion of "Bounded Rationality" [7]. "Bounded Rationality" takes into account the cognitive limitations of the decision maker, limitations of both knowledge and computational capacity.

There are many biases and psychological factors that influence individual investors' investment decisions. Mostly investors hold on to "losers" too long and sell "winners" too early because they fear losses much more than they value gains. This behavior is explained by "prospect theory", which contends that utility depends on deviation from moving reference points rather than absolute wealth [8]. Another bias documented by Solt \& Statman [9] for growth companies is over confidence in forecasts, resulting in over-estimation of growth rates for growth companies and over emphasize good news and ignore negative news for these firms. Standard Finance assumes people to follow the rules of probability in decision making under uncertainty, but in violation to Bayes' rule, most people over-react to unexpected and dramatic news events [10]. This irrational behavior of overreaction is explained by behavioral finance theory [11]. Opiela [12] argued that behavioral understanding of decision making process not only is helpful to individual investors but also benefit investment planners to understand the biases to which they themselves and their clients are prone to while taking investment decisions. This way they help themselves and also educate their clients to overcome these biases by following suggestions of experts.

The individual investors have inherent tendency towards irrationality is argued by many behavioral scientist [13] [14] [15] [16]. Contrary to the assumption of standard finance theory, this new field of behavioral finance neither assumes that human beings are perfectly rational nor it assumes that imperfection in market mechanism leads to market irrationality [17]. However, it assumes that stock markets are composed of imperfectly rational players in imperfect markets [18]. Psychologists have developed a substantial body of knowledge demonstrating psychological traits and bottlenecks in expert decision making in general [19] and economic decision making in particular [20]. The review of literature reproduced above clearly depicts that there are many psychological traits which do affect individual investors while they take investment decisions in stock market and as such it is required to predict important behavioral biases that can be integrated with standard finance theory assumptions so as to develop unified finance strategy useful in investment decisions.

\section{Methodology}

The current study uses review of literature and information received from active 
investors through interview to identify the dimensions that are possible psychological traits affecting individual investors while they take any investment decision. During the interview process, the investors were asked to indicate the relevant biases that they perceive as an important traits affecting their investment decisions. Finally, in addition to ten main psychological traits identified by the various experts having greater influence among investors in the stock market, we have included the faith as an important bias identified through interview process of investors. Deduction approach of research has been used in present study because the main objective of the study is to identify the psychological traits that influence the decision making of individual investors, which are already out there, without inferring and building theory.

In the context, a questionnaire was prepared, which do commensurate with deductive approach. The original questionnaire covering all the identified dimensions had 66 statements. The data regarding investors was obtained from the depository participants working in the state of Jammu and Kashmir (India). As per the data obtained from them, the total investor population in all the three divisions of Jammu and Kashmir is only 22,040, out of them only 2300 are active investors. The sample size of 330 investors is derived at 95 percent level of significance by using the on-line calculator but population frame for this was considered only among the active investors, as it is believed that active investors' psychological traits could only be properly evaluated. The questionnaire was then piloted on 200 active investors and Exploratory Factor Analysis (EFA) was applied to identify the factors that are more effective in influencing the investment decisions. It is useful technique to analyze the structure of correlations amongst different variables so as to identify a set of core dimensions, called factors [21] and as such, EFA is used to reduce the number of factors that do not meet criteria of the analysis [22]. The questionnaire used 5-point Likert Scale ranging from 1 (Strongly Disagree) to 5 (Strongly Agree). This scale was preferred because it is more reliable and easier than other scales in terms of reliability and scaling. After the elimination, addition and rephrasing of several questions, the final questionnaire covering only seven dimension and containing only 33 statements, was drafted.

Around 350 questionnaires were distributed, out of which only 303 were found to be usable and hence were retained, resulting in the participation rate of 87\%. The Statistical Package for Social Science (SPSS-19) was used for conducting Exploratory Factor Analysis and this technique for data reduction through which variable that are related are grouped together under various factors, resulting in categorization of large number of variables under few dimensions or factors only. Thus, Factor Analysis minimizes data and redevelops the structures on the basis observed relationship between the variables. Factor Analysis is of two types, Explanatory and Confirmatory. Since the questionnaire used is newly constructed and as such Explanatory Factor Analysis was carried out. Lastly, multiple regression analysis was carried out to determine the impact of each of 
these biases on the rationality of individual investors. Takingclue from the EFA and review of literature, the introduction of the various variables used in the present study is give below:

\subsection{Overconfidence and Optimism}

Overconfidence is defined as the tendency of an investor to overestimate the probability of achieving one's objectives as a result of a presumptuous belief in one's abilities or attribute as they may be used to bring about a particular outcome. On the other hand, Optimism can be defined as the tendency or inclination to perceive an event or action as more likely to result in a favorable outcome, irrespective of the objective probability of that outcome actually occurring.

\subsection{Heuristics}

Heuristics are simply rules of thumb or gut feeling that helps one to arrive at a decision, especially under the complex situations. Humanly it is not possible to make use of all information but with experience man learns the art of decision making out of the portion of this information. This gives rise to some "Rules of Thumb" that can be used in similar situations. This phenomenon is known as "Use of Heuristics". However, heuristics used as strategy do not always give correct information and can lead to "Cognitive Errors".

\subsection{Rationality}

It is a mode of behavior that is suitable to the achievement of specified goals within the boundaries of certain conditions and constraints [23]. A rational behavior decision making is based on making choices that result in the most optimal level of benefit or utility for the individual. However, Statman M. [24] proposed that a rational investor should analyze and evaluate information comprehensively to succeed in their investment activities.

\subsection{Faith}

It is the strong belief in the doctrines of religion, based on spiritual conviction rather than proof. The term "Faith" includes two aspects. First, when investors get new information, they update and renew their beliefs in the approved manner, in the way specified by Bayes' law. Secondly, as in Savage's notion of subjective expected utility, investors make conviction rather than proof. It is the assurance of things not seen and trusting in something you cannot explicitly prove. The faith contains two aspects: intellectual assent and trust. Intellectual assent believes something to be true and trust is actually relying on the fact that the something is true.

\subsection{Pessimism}

It is the overestimation of the probabilities and harmful effects of negative future 
events. The pessimism bias is a cognitive bias that causes people to overestimate the likelihood that bad things will happen to them. This bias distorts individual's thought process, and can be detrimental to your emotional wellbeing, which is why it is strongly associated with stock market decision making. This bias is most common in depressed individuals. This bias has been found to be more prevalent among women than men.

\subsection{Herd Behavior}

Herding means following the actions of others without any logic/reason behind it, resulting in amplified mass reaction. Herding in the stock market is defined as mutual imitation leading to a convergence of actions. In stock markets people normally follow a crowd without taking cognizance of the fundamentals of the company.

\subsection{Confirmation}

Confirmation bias is a psychological phenomenon wherein investors look for information that supports their prior belief/information and decision and as a result, they under/over value the stocks of otherwise generally popular companies. Hence, individual investors make very poor investment decisions because they always look for information that confirms his prior belief.

\section{Results and Discussion}

\subsection{Principal Component Analysis}

The main objective of the study was to identify the various psychological traits of individual investors and to analyse their impact on their rationality. In order to identify various psychological traits of individual investors Principal Component Analysis was used on the primary data collected through well designed questionnaire. After conducting the EFA on the data collected, 33 statements were observed to have significant loading and were sorted under seven different dimensions. Principal Components Analysis and varimax rotation were applied. Series of rotations were carried out wherein statements that were not significant enough were taken out in each rotation, resulting in the reduction of the data from 66 statements to 33 statements categorized under 7 dimensions including rationality. As is evident from Table 1, the total variance explained by these seven factors brought out by the factor analysis account for $62.14 \%$ of the total explained variance, which is quite good as this is a social science research and total variance explained should be more than $50 \%$. The results presented in Table 1, reveals that explained variance for Overconfidence and Optimism, Heuristics, Rationality, Faith, Pessimism, Herd and Confirmation dimensions is witnessed at 13.238, 11.606, 10.930, 7.851, 6.645, 5.955 and 5.913 respectively. Moreover, it also evident from Table 1, the eigenvalues of all the seven dimensions are greater than 1 , which is again the criterion for retention of variables. Although $7^{\text {th }}$ dimension also has Eigenvalue greater than one, but this 
Table 1. Summary results of scale purification dimensions, factor loadings, communalities, eigenvalue and percentage of explained variance.

\begin{tabular}{|c|c|c|c|c|c|c|}
\hline 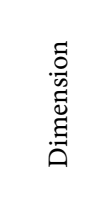 & 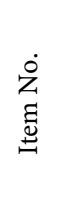 & Elements & 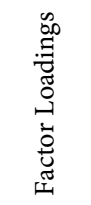 &  & 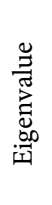 & 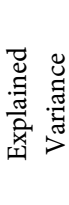 \\
\hline \multirow{7}{*}{ 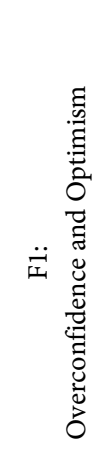 } & $\mathrm{V}_{1}$ & You have better knowledge and skill compared to others & 0.560 & 0.708 & \multirow{8}{*}{$\underset{\substack{6 \\
+}}{+\infty}$} & \multirow{8}{*}{$\stackrel{\infty}{\sim}$} \\
\hline & $\mathrm{V}_{3}$ & $\begin{array}{l}\text { You are confident about securities you invest in and never regret for your past investment } \\
\text { decisions }\end{array}$ & 0.724 & 0.680 & & \\
\hline & $\mathrm{V}_{4}$ & You have more expertise to select good securities better than others & 0.578 & 0.738 & & \\
\hline & $\mathrm{V}_{5}$ & You are able to evaluate and manage your portfolio on your own & 0.573 & 0.717 & & \\
\hline & V6 & You have better understanding of the security market & 0.640 & 0.589 & & \\
\hline & $\mathrm{V}_{7}$ & $\begin{array}{l}\text { NSE and BSE indices though are declining yet you believe it will gain momentum, as such } \\
\text { you continue to increase your investment }\end{array}$ & 0.740 & 0.704 & & \\
\hline & $\mathrm{V}_{20}$ & You are always confident that Indian Stock has high potential of growth & 0.675 & 0.508 & & \\
\hline \multirow{8}{*}{ 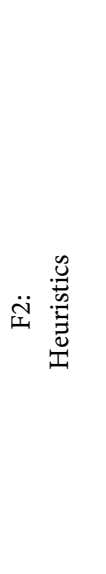 } & $\mathrm{V}_{30}$ & You usually take good financial decisions & 0.675 & 0.582 & & \\
\hline & $\mathrm{V}_{2}$ & $\begin{array}{l}\text { You avoid selling stocks that have decreased in value and readily sell stocks that have } \\
\text { increased in value }\end{array}$ & 0.836 & 0.702 & \multirow{7}{*}{$\underset{\mathscr{\sigma}}{+}$} & \multirow{7}{*}{ 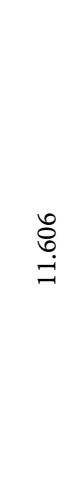 } \\
\hline & $\mathrm{V}_{15}$ & While taking investment decisions you prefer to go with your gut feeling & 0.688 & 0.680 & & \\
\hline & $\mathrm{V}_{17}$ & Before you purchase a stock you do conduct its thorough technical analysis & 0.838 & 0.708 & & \\
\hline & $\mathrm{V}_{27}$ & You evaluate increase or decrease in the share prices with reference to some fixed price & 0.579 & 0.550 & & \\
\hline & $\mathrm{V}_{28}$ & $\begin{array}{l}\text { Recent information about a stock always comes to your mind and affects your stock } \\
\text { selection }\end{array}$ & 0.635 & 0.733 & & \\
\hline & $\mathrm{V}_{29}$ & $\begin{array}{l}\text { If a particular sectors performs nicely, you believe that all stocks of that sector will have } \\
\text { better performance }\end{array}$ & 0.580 & 0.532 & & \\
\hline & $\mathrm{V}_{31}$ & You prefer to buy stocks if buy volume of such stock is healthy. & 0.694 & 0.514 & & \\
\hline \multirow{7}{*}{ 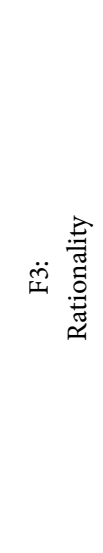 } & $\mathrm{V}_{8}$ & $\begin{array}{l}\text { You base all your decisions regarding stock selection on fresh publicly available } \\
\text { information such as EPS, DPS, PER, stock splits etc. }\end{array}$ & 0.625 & 0.573 & \multirow{7}{*}{  } & \multirow{7}{*}{$\begin{array}{c}\grave{\infty} \\
\grave{O}\end{array}$} \\
\hline & $\mathrm{V}_{9}$ & You feel security prices reflect all new publicly information. & 0.568 & 0.574 & & \\
\hline & $\mathrm{V}_{19}$ & $\begin{array}{l}\text { You feel stock prices adjust quickly to new publicly available information and this } \\
\text { information is free and is quickly received by the market }\end{array}$ & 0.741 & 0.567 & & \\
\hline & $\mathrm{V}_{21}$ & $\begin{array}{l}\text { You feel no investor or group of investors have monopolistic access to information having } \\
\text { impact on stock prices. }\end{array}$ & 0.710 & 0.574 & & \\
\hline & $\mathrm{V}_{22}$ & $\begin{array}{l}\text { You feel past return and other historical market data have no relationship with future } \\
\text { return and do not influence your investment decisions. }\end{array}$ & 0.640 & 0.512 & & \\
\hline & $\mathrm{V}_{24}$ & You never pay heed towards any rumour about stock/market as whole & 0.762 & 0.641 & & \\
\hline & $\mathrm{V}_{32}$ & $\begin{array}{l}\text { You only use historical data to estimate future values and invest on the basis of these } \\
\text { estimates. }\end{array}$ & 0.510 & 0.667 & & \\
\hline \multirow{4}{*}{ 蓎 壱 } & $\mathrm{V}_{10}$ & You normally invest in Islamic Shari'ah complaint stocks only. & -0.645 & 0.669 & \multirow{4}{*}{$\stackrel{\substack{+\stackrel{N}{i}}}{i}$} & \multirow{4}{*}{ 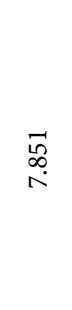 } \\
\hline & $\mathrm{V}_{12}$ & $\begin{array}{l}\text { You invest in equity market because there is no predetermined return specified on the } \\
\text { stocks you buy. }\end{array}$ & 0.614 & 0.674 & & \\
\hline & $\mathrm{V}_{23}$ & $\begin{array}{l}\text { You invest only in equity stock market or the business ventures where you expect share of } \\
\text { profit contrary to sure interest income. }\end{array}$ & 0.678 & 0.757 & & \\
\hline & $\mathrm{V}_{19}$ & $\begin{array}{l}\text { You choose only stocks of those companies who normally do not have debt in capital } \\
\text { structure. }\end{array}$ & 0.705 & 0.702 & & \\
\hline
\end{tabular}




\section{Continued}

\begin{tabular}{|c|c|c|c|c|c|c|}
\hline \multirow{3}{*}{ 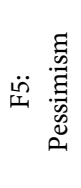 } & $\mathrm{V}_{11}$ & Increasing stock price will soon be followed by decreasing trend. & 0.676 & 0.482 & \multirow{3}{*}{ 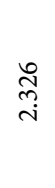 } & \multirow{3}{*}{$\underset{b}{\stackrel{\leftrightarrow}{0}}$} \\
\hline & $\mathrm{V}_{14}$ & Investments are usually risky as gains are rare and losses are frequent & 0.655 & 0.508 & & \\
\hline & $\mathrm{V}_{33}$ & $\begin{array}{l}\text { You feel that Indian stock market will face severe crash in future and most of stock will } \\
\text { experience decline sharply. }\end{array}$ & 0.682 & 0.514 & & \\
\hline \multirow{3}{*}{ 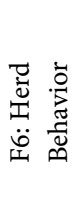 } & $\mathrm{V}_{13}$ & $\begin{array}{l}\text { You consider newsletters an important source of information and thus consider them } \\
\text { before taking an investment decision }\end{array}$ & 0.815 & 0.771 & \multirow{3}{*}{$\begin{array}{l}\stackrel{+}{\infty} \\
\stackrel{0}{0} \\
\stackrel{1}{1}\end{array}$} & \multirow{3}{*}{ ผn } \\
\hline & $\mathrm{V}_{16}$ & The decisions of other investors to buy or sell stocks have influence on your investment & 0.514 & 0.579 & & \\
\hline & $\mathrm{V}_{18}$ & $\begin{array}{l}\text { You think following some expert advice is a good idea as they possess more knowledge } \\
\text { compared to you }\end{array}$ & 0.748 & 0.508 & & \\
\hline \multirow{2}{*}{. } & $\mathrm{V}_{25}$ & $\begin{array}{l}\text { After developing an opinion about the stock market performance you seek opinion of } \\
\text { others before taking final decision to invest in the market. }\end{array}$ & 0.600 & 0.669 & \multirow{2}{*}{ 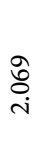 } & \multirow{2}{*}{$\begin{array}{l}\ddot{m} \\
\text { in }\end{array}$} \\
\hline & $\mathrm{V}_{26}$ & $\begin{array}{l}\text { You never care about bad news about the stock that you have purchased on the basis of } \\
\text { self-created opinion. }\end{array}$ & 0.747 & 0.661 & & \\
\hline
\end{tabular}

dimension of rationality is used as independent variable for the analysis.

Most of the factor loadings were greater than 0.50 , implying a reasonably high correlation between extracted factors and the individual items. The communalities of 33 items ranged from 0.508 to 0.771 indicating that large amount of variance have been extracted by the factor solution. In addition, one item namely you have sufficient knowledge of Indian stock market. (V13) was not considered for further analysis as it had fallen into two dimensions. All identified factors are labeled as F1-Overconfidence and Optimism, F2-Heuristics, F3-Rationality, F4-Faith, F5-Pessimism, F6-Herd Behavior, and F7-Confirmation.

To test the reliability of the scale Cronbach's Alpha was used. As is evident from Table 2, the present generated scale achieved the scores of 0.802 , which is highly acceptable reliability coefficient, as Nunally [25] suggested that Cronbach's Alpha should be at least 0.7 to make sure that the measurements are reliable, however, Shelby [26] argued that Cronbach's Alpha of over 0.6 is also acceptable. The Cronbach's Alpha was also applied to each dimension separately in order to test their reliability. As is evident from Table 2 that the computed Cronbach's Aplha was recorded at 0.819, 0.866, 0.804, 0.637, 0.614, 0.666, and 0.625 for Overconfidence and optimize (F1), Heuristics (F2), Rationality (F3), Faith (F4), Pessimism (F5), Herd Behavior (F6), and Confirmation (F7) respectively. All these coefficients reveal acceptable level of reliability.

Kaiser Meyer Olkin (KMO) was performed, which presents the level of suitability of using EFA for the collected data in terms of sample adequacy. Generally, it is argued that the sample size should be 3 - 5 times of the number of statements. So before proceeding further it was important to check whether the results of EFA are acceptable or not and to accept the results KMO value should be significant. The test value for Kaiser-Meyer-Olkin (KMO) of higher than $60 \%$ (i.e. 0.6) denotes the adequacy of sample size [27]. Hence, EFA as presented in Table 3 reveals acceptable level as KMO score of 0.660 is $>0.6$ (Table 3).

Again the Bartlett's Test of Sphericity, which shows the strength of the relationship among variables, tests the null hypothesis that the correlation matrix is 
Table 2. Reliability test of identified dimensions.

\begin{tabular}{lccccccc}
\hline Dimensions $\begin{array}{c}\text { Overconfidence } \\
\text { and Optimism }\end{array}$ & Heuristics & Rationality & Faith & Pessimism & $\begin{array}{c}\text { Herd } \\
\text { Behavior }\end{array}$ & Confirmation \\
\hline $\begin{array}{l}\text { Cronbach's } \\
\text { Alpha }\end{array}$ & 0.819 & 0.866 & 0.804 & 0.637 & 0.614 & 0.666 & 0.625 \\
\begin{tabular}{l} 
No. of Items \\
\multicolumn{2}{l}{ Overall Reliability }
\end{tabular} & & 7 & 7 & 3 & 3 & 3 & 2 \\
\end{tabular}

Table 3. KMO and BARTLETT's test.

\begin{tabular}{ccc}
\hline \multicolumn{2}{c}{ Kaiser-Meyer-Olkin Measure of Sampling Adequacy. } & 0.660 \\
\hline & Approx. Chi-Square & 4293.233 \\
Bartlett's Test of Sphericity & df & 595 \\
& Sig. & $0.000^{*}$ \\
\hline
\end{tabular}

${ }^{\star}$ Significant at $1 \%$ level.

an identity matrix. An identity matrix is matrix in which all of the diagonal elements are 1 and all off diagonal elements are 0 . For the factor analysis to be acceptable it is important that at least some of the variables should be correlated, otherwise each statement will come about as a separate variable and cannot be included under some factors. The significant value of this test should be less than 0.05 so that we can say that the null hypothesis can be rejected and hence the alternate hypothesis that there is correlation between the factors can be accepted. From Table 2, we can see that the Bartlett's Test of Sphericity is significant, i.e., its associated probability is less than 0.05 . In fact, revealed Chi-Square 4293.233 $(P<0.000)$, verifies that correlation matrix was with an identity matrix, thus validating the suitability of factor analysis.

\subsection{Regression Analysis}

Multiple regression analysis has been carried out to see the influence of various biases on the rationality of individual investors. This analysis has been used meticulously because any one factor individually may not explain any phenomenon adequately until and unless it acts in the association with other significant variables. For this purpose the variables have been entered in the model according to the significance of correlations.

The results of stepwise multiple regression analyses are presented in Table 4. It is seen that F4 (Faith) appeared as the first factor and thereafter subsequent factors were added one by one to show the maximum model fit. F4 explains 17 per cent of variations in rationality of investors and one unit change in it will lead to -0.278 units' deviation from rationality. The value of $\mathrm{R}^{2}$ is 0.170 and Adjusted $R^{2}$ is 0.167 , are significant at 5 per cent level of significance. The results of first regression model also show that F4 is a strong individual factor that influences the rationality of investors. With the introduction of next variable, F2 
Table 4. Step.wise multiple regression analysis results.

\begin{tabular}{|c|c|c|c|c|c|c|c|c|c|c|c|c|}
\hline & Intercept & F4 & F2 & F7 & F5 & F1 & F6 & $\mathbf{R}$ & $\mathbf{R}^{2}$ & Adj. $R^{2} R$ & ${ }^{2}$ Change & F Ratio \\
\hline I & $\begin{array}{c}2.214 \\
(18.211)\end{array}$ & $\begin{array}{c}-0.278 \\
(7.843)^{\star}\end{array}$ & & & & & & 0.412 & 0.170 & 0.167 & 0.170 & $61.518^{*}$ \\
\hline II & $\begin{array}{c}1.492 \\
(9.068)\end{array}$ & $\begin{array}{c}-0.219 \\
(-6.288)^{*}\end{array}$ & $\begin{array}{c}0.279 \\
(6.133)^{\star}\end{array}$ & & & & & 0.512 & 0.262 & 0.257 & 0.093 & $37.618^{*}$ \\
\hline III & $\begin{array}{c}1.182 \\
(6.413)\end{array}$ & $\begin{array}{l}-0.204^{\star} \\
(-5.917)\end{array}$ & $\begin{array}{l}0.289^{\star} \\
(6.471)\end{array}$ & $\begin{array}{l}0.103^{*} \\
(3.484)\end{array}$ & & & & 0.539 & 0.291 & 0.284 & 0.029 & $12.138^{\star}$ \\
\hline IV & $\begin{array}{c}0.896 \\
(1.784)\end{array}$ & $\begin{array}{l}-0.191^{\star} \\
(-5.645)\end{array}$ & $\begin{array}{c}0.253^{*} \\
(5.655)\end{array}$ & $\begin{array}{l}0.116^{*} \\
(3.982)\end{array}$ & $\begin{array}{l}0.131^{*} \\
(3.819)\end{array}$ & & & 0.569 & 0.324 & 0.315 & 0.033 & $14.583^{*}$ \\
\hline $\mathrm{V}$ & $\begin{array}{c}0.765 \\
(3.842)\end{array}$ & $\begin{array}{l}-0.174^{*} \\
(-5.087)\end{array}$ & $\begin{array}{l}0.211^{\star} \\
(4.503)\end{array}$ & $\begin{array}{l}0.114^{*} \\
(3.947)\end{array}$ & $\begin{array}{l}0.132^{*} \\
(3.908)\end{array}$ & $\begin{array}{l}-0.099^{*} \\
(-2.701)\end{array}$ & & 0.583 & 0.340 & 0.329 & 0.016 & $7.297^{\star}$ \\
\hline VI & $\begin{array}{c}0.746 \\
(-3.764)\end{array}$ & $\begin{array}{l}-0.160^{\star} \\
(-4.635)\end{array}$ & $\begin{array}{l}0.180^{\star} \\
(3.682)\end{array}$ & $\begin{array}{l}0.092^{\star} \\
(3.035)\end{array}$ & $\begin{array}{l}0.129^{*} \\
(3.835)\end{array}$ & $\begin{array}{l}-0.093^{\star} \\
(-2.536)\end{array}$ & $\begin{array}{l}-0.077^{\star} \\
(-2.099)\end{array}$ & -0.592 & 0.350 & 0.337 & 0.010 & $4.407^{\star}$ \\
\hline
\end{tabular}

${ }^{*}$ Significant at 5 percent.

(Heuristics) it is revealed that both the factors taken together explain 26.2 per cent of the variations and both the factors are significant in explaining the change in rationality of investors. F4 is of greater importance, as one unit change in F4 will lead to -219 units' variation in rationality, whereas the increase associated with $\mathrm{F} 1$ is -0.279 units. The value of $\mathrm{R}^{2}$ is 0.291 and Adjusted $\mathrm{R}^{2}$ is 0.284 are significant at 5 per cent level of significance. However, F4 decreases the rationality while as $\mathrm{F} 2$ has potential to improve the same.

When next factor F7 (Confirmation) is added, it becomes clear that three factors collectively explain 29.10 per cent of variation in rationality of investors. However, F4 is now not as important as the F2 as one unit change in F2 will lead to 0.289 units positive change in rationality, whereas the F4 is negatively affecting rationality and will bring down rationality by -0.204 units by change in one unit of F4. In $3^{\text {rd }}$ model the value of $R^{2}$ is 0.291 and Adjusted $R^{2}$ is 0.284 , which is significant at 5 per cent level of significance. The results of third regression model reveal that Heuristics and Confirmation has statistically significant but positive influence investors rationality while as Faith is also statistically significant but it reduces the rationality among investors. In $4^{\text {th }}$ model F5 (Pessimism) is introduced and it has improved $\mathrm{R}^{2}$ and these four factors explain 32.4 per cent variation in rationality. However, F4 and F2 have greater potential to have impact on investors' rationality though both work in opposite direction. This model is statistically also significant. In $5^{\text {th }}$ model $\mathrm{F} 1$ is introduced and it has improved $\mathrm{R}^{2}$ and now these five factors together explain 34 per cent variation in rationality. However, F4 and F2 continue to be significant factors explaining investors' rationality. The $\mathrm{F} 1$ is also a main potential factor to deviate investors' rationality negatively, as one unit of change in this factor will bring -0.099 units change in rationality. This model is statistically also significant. 
Lastly, with the introduction of last factor F6 (Herd Behaviour), it is seen that all six factors [28] significant and the coefficient of determination $\left(\mathrm{R}^{2}\right)$ has marginally increased to 35 per cent. Thus, these factors explain 35 per cent variations in rationality. The value of $R^{2}$ is 0.350 and Adjusted $R^{2}$ is 0.337 , which is significant at 5 per cent level of significance. It is evident that factors F4 (Faith), F1 (Overconfidence and Optimism) and F6 (Herd Behaviour) affect rationality of investors negatively and as such they don't take rational decisions in the market. While as F2 (Heuristics), F7 (Confirmation) and F5 (Pessimism) seems to have positive impact on rationality and as such increases rational behaviour of investors.

Table 5 presents the influence of various factors on the rationality of investors. The results of the analysis reveal; firstly, the multiple correlation coefficients which measure the degree of relationship between the independent variables are -0.592 and this indicates the relationship between these variables is strong and negative. Secondly, the coefficient of determination $\left(\mathrm{R}^{2}\right)$ measures goodness of fit in terms of the proportion of the variation in the dependent variable indicates that 35 per cent variability in investor's rationality is explained by F4, F2, F7, F5 and F1. Thirdly, to diagnose autocorrelation problem, Durbin Watson Test is used and Durbin Watson Test is 1.426 is less than rule of thumb of 2 and thus there is no serial correlation. Thirdly, F-value (4.407) is significant at 5 per cent level significance as $p$-value $(0.037)$ is less than $5 \%$ and as such one can deduce that all null hypotheses are rejected and overall regression coefficients are accepted. Further, the value of adjusted $\mathrm{R}^{2}$ and $\mathrm{F}$ value also confirms that final model presented in Table 5 is a good statistical fit. Finally, VIF method used in the study confirms that there is no multicollinearity problem as VIF presented in Table 6 for all six models is less than Rule of Thumb of 10.

\section{Conclusion}

The study lime lights the fact that individual investors are influenced by various psychological traits while they make any investment decision. The main factors identified by the EFA are overconfidence and optimism, heuristics, faith, pessimism, herd behavior and confirmation biases. The regression analysis reveals that 35 percent variation in rationality of individual investors is explained by

Table 5. Final regression model summary (Response Variable Rationality).

\begin{tabular}{|c|c|c|c|c|c|c|c|}
\hline $\begin{array}{l}\text { Predictor } \\
\text { Variables }\end{array}$ & Constant & $\begin{array}{l}\text { Faith } \\
(\mathrm{F} 4)\end{array}$ & $\begin{array}{l}\text { Heuristics } \\
\text { (F2) }\end{array}$ & $\begin{array}{l}\text { Confirmation } \\
\text { (F7) }\end{array}$ & $\begin{array}{c}\text { Pessimism } \\
\text { (F5) }\end{array}$ & $\begin{array}{c}\text { Overconfidence } \\
\text { F1 }\end{array}$ & $\begin{array}{l}\text { Herd Beh. } \\
\text { F6 }\end{array}$ \\
\hline$\beta$ & 0.746 & $-0.160^{*}$ & $0.180^{*}$ & $0.092^{*}$ & $0.129^{*}$ & $-0.093^{*}$ & $-0.077^{\star}$ \\
\hline$p$ value & $(0.000)$ & $(0.000)$ & $(0.000)$ & $(0.003)$ & $(0.000)$ & $(0.012)$ & $(0.037)$ \\
\hline t-value & -3.764 & -4.635 & 3.682 & 3.035 & 3.835 & -2.536 & -2.099 \\
\hline \multicolumn{2}{|c|}{ Degrees of Freedom $=1$} & \multicolumn{2}{|c|}{$\mathrm{R}=-0.592$} & \multicolumn{2}{|c|}{$\mathrm{R}^{2}=0.350$} & \multicolumn{2}{|c|}{ Adjusted $\mathrm{R}^{2}=0.337$} \\
\hline \multicolumn{2}{|c|}{$\begin{array}{c}\text { F Value }=4.407^{\star} \\
(0.037)\end{array}$} & \multicolumn{4}{|c|}{ Durbin Watson $=1.426$} & \multicolumn{2}{|l|}{ S.E. $=0.34101$} \\
\hline
\end{tabular}

${ }^{*}$ Significant at 1 percent. 
Table 6. Multiple regression analysis results.

\begin{tabular}{ccccccccc}
\hline \multirow{2}{*}{ Model } & \multicolumn{2}{c}{$\begin{array}{c}\text { Unstandardized } \\
\text { Coefficients }\end{array}$} & $\begin{array}{c}\text { Standardized } \\
\text { Coefficients }\end{array}$ & t-Value & $\boldsymbol{P}$-Value & \multicolumn{2}{c}{$\begin{array}{c}\text { Co-linearity } \\
\text { Statistics }\end{array}$} \\
\cline { 2 - 3 } & $\boldsymbol{\beta}$ & Std. Error & $\boldsymbol{\beta}$ & & & Tolerance & VIF \\
\hline Constant & 0.746 & 0.198 & & -3.764 & 0.000 & & \\
F4 & -0.160 & 0.035 & -0.237 & -4.635 & 0.000 & 0.838 & 1.194 \\
F2 & 0.180 & 0.049 & 0.205 & 3.682 & 0.000 & 0.711 & 1.407 \\
F7 & 0.092 & 0.030 & 0.153 & 3.035 & 0.003 & 0.860 & 1.163 \\
F5 & 0.129 & 0.034 & 0.188 & 3.835 & 0.000 & 0.917 & 1.091 \\
F1 & -0.093 & 0.037 & -0.132 & -2.536 & 0.012 & 0.814 & 1.228 \\
F6 & -0.077 & 0.037 & -0.117 & -2.099 & 0.037 & 0.712 & 1.405 \\
\hline
\end{tabular}

these psychological traits. However, study has made one important manifestation that three biases namely faith, overconfidence and optimism, and herd behavior deviates individual investors from their rationality while as, heuristics, confirmation and pessimism psychological traits at time makes individual investors more rational. The main contribution of this study is that it has identified faith as one strong psychological trait which does influence individual investors' rational behavior negatively. This study asserts that there is an urgent need to have the unified theory of behavioural finance and standard finance, the emphasis of which should be in identifying portfolio anomalies that can be explained by various psychological traits in individual investors for bringing greater efficiency in our stock markets. The behavioural portfolio management should be aimed at by building superior portfolios based on the pricing distortions created by investor's emotional behaviour [28]. The behavioural portfolio management can be constructed to reduce the emotional volatility by dividing into a portion to meet short term needs and a portion to build long term wealth. The short term portfolio is built in consonance with psychological traits while as the long term portfolio is build by focusing on expected returns and fundamentals of the market. In this context, all the distortions created by emotional traits should be properly analysed and then should be used to build successful strategies to develop behavioural portfolio management theory in consistent with efficient market hypothesis.

\section{References}

[1] Olsen, R. (1998) Behavioral Finance and Its Implications for Stock-Price Volatality. Investment Management and Research Financial Analysis Journal, 2, 10-18. https://doi.org/10.2469/faj.v54.n2.2161

[2] Fama, E.F. (1970) Efficient Capital MArkets: A Review of Theory and Empirical Work. Journal of Finance, 25, 383-417. https://doi.org/10.2307/2325486

[3] Fama, E.F. (1991) Efficient Capital Markets: A Review of Theory and Empirical Work. Journal of Finance, 46, 1575-1617. https://doi.org/10.1111/j.1540-6261.1991.tb04636.x

[4] Kiyilar, M. and Acar, O. (2009) Behavioural Finance and the Study of the Irrational Financial Choices of Credit Card Users. Annales Universitatis Apulensis Series Oe- 
conomica, 11, 457-468.

https://papers.ssrn.com/sol3/papers.cfm?abstract_id=2216637

[5] Spindler, G. (2011) Springerlink.com.

http://www.behaviouralfinance.net/behavioural-finance.pdf

[6] Rabin, M. and Thaler, R.H. (2001) Anomalies: Risk Aversion. Journal of Economic Prespectives, 15, 219-232. https://doi.org/10.1257/jep.15.1.219

[7] Uzar, C. and Akkay, G.C. (2013) The Mental and Behavioral Mistakes Investors Make. International Journal of Business and Management Studies, 5, 120-128.

[8] Kahneman, D. and Tversky, A. (1979) Prospect Theory: An Analysis of Decision Under Risk. Econometrica, 47, 263-291. https://doi.org/10.2307/1914185

[9] Solt, M. and Statman, M. (1989) Good Companies, Bad Stocks. Journal of Portfolio Management, 15, 39-45. https://doi.org/10.3905/jpm.1989.409219

[10] Bondt, W.F. and Thaler, R. (1985) Does the Stock Market Overreact? The Journal of Finance, 40, 793-805. https://doi.org/10.1111/j.1540-6261.1985.tb05004.x

[11] Reedman, E.M. (2005) An Examination of the Overreaction Anomaly: Implications for the Allocation of Investment Capital. Working Paper.

[12] Opiela, N. (2005) Rational Investing Despite Irrational Behaviors. Journal of Financial Planning, 1-6.

[13] Statman, M. (1995) Behavioral Finance Versus Standard Finance. http://www.aiinfinance.com/Statman.pdf https://doi.org/10.2469/cp.v1995.n7.4

[14] Shefrin, H. (2007) Behavioral Finance: Biases, Mean-Variance Returns and Risk Premium. Equity Research and Valuation Techniques Conference, CFA, Boston, 4-11.

[15] Shane, F. (2005) Cognitive Reflection and Decision Making. Journal of Economic Prespectives, 19, 25-42. https://doi.org/10.1257/089533005775196732

[16] Thaler, R.H. (2008) Mental Accounting and Consumer Choice. Marketing Science, 27, 15-25. https://doi.org/10.1287/mksc. 1070.0330

[17] Thaler, R. (1980) Towards a Positive Theory of Consumer Choice. Journal of Economic Behavior and Organisation, 1, 39-60.

https://doi.org/10.1016/0167-2681(80)90051-7

[18] DeBondt, W. (1998) A Portrait of the Individual Investor. European Economic Review, 42, 831-844. https://doi.org/10.1016/S0014-2921(98)00009-9

[19] Camerer, C. (1999) Behavioral Economics: Reunifying Psychology and Economics. Proceedings of the National Academy of Sciences, 96, 10575-10577. https://doi.org/10.1073/pnas.96.19.10575

[20] Lopes, L.L. (1994) Psychology and Economics: Perspectives on Risk, Cooperation and the Market Placeo. Annual Review of Psychology, 45, 197-227.

https://doi.org/10.1146/annurev.ps.45.020194.001213

[21] Ghauri, P. and Gronhaug (2010) Research Methods in Business Studies. Fourth Edition, Pearson Education Limited, London.

[22] O’Brien (2007) Factor Analysis: An Overview in the Field of Management. Physiotherapy Canada, 59, 142-155. https://doi.org/10.3138/ptc.59.2.142

[23] Simon, H.A. (1982) Models of Bounded Rationality: Empirically Grounded Economic Reason. Vol. 3, MIT Press, Cambridge.

[24] Statman, M. (1988) Investor Psychology and Market Inefficiencies. ICFA Containing Education Series, 2, 29-35. https://doi.org/10.2469/cp.v1988.n2.6 
[25] Nunally, J. (1978) Psychometric Theory. McGraw Hill Book Company, New York.

[26] Shelby, L. (1989) Beyond Cronbach's Alpha: Considering Confirmatory Factor Analysis and Segmentation. Human Diversifications of Life, 12, 47-66.

[27] Tabachnik, B. and Fidel, L. (2011) Using Multivariate Statistics. Allyn and Bacon, Needham Heights.

[28] Howard, C.T. (2014) Behavioral Portfolio Management. Harriman House Ltd., Petersfield. 